\title{
Comparative Evaluation of Growth and Flowering Characteristic of Alstroemeria Varieties under Sikkim Condition
}

\author{
Sujit Rai* and Manju Rana
}

Singtam South District Namchi, Sikkim-737126, India

*Corresponding author

\section{A B S T R A C T}

\section{Keywords}

Alstroemeria and performance evaluation

Article Info

Accepted:

10 July 2019

Available Online:

10 August 2019

Alstroemeria hybrida is one of the important cut flower grown for domestic as well as for export market. Alstroemeria gaining popularity because of its free use in floral arrangement, beds, pots, season hedge etc. An experiment was conducted to evaluate the performance of eight cultivars of Alstroemeria under poly house conditions. The results revealed that among the selected eight varieties, Rosita (V1) was superior to other in reference to number of leaves per plant at both flower bud emergence and flower harvesting stage with maximum leaf area, number of cymes and number of florets per spike, and total florets opened per spike whereas, New Pink (V3) variety recorded minimum days for rhizome to sprout with maximum plant height and peduncle length. Maximum number of florets opened per spike with maximum vase life was recorded in Picanto (V2).

\section{Introduction}

Alstroemeria hybrida which is commonly known as Alstroemeria or as lily of the Incas or Peruvian lily belongs to the family Alstroemeriaceae, which bears flowers of attractive colour and an extended shelf life.

It is used for cut flowers or as potted or garden plants (Bridgen, 1997). It is an indigenous to South America (De Hertogh, 1989 and Robinson, 1983). The flowers are solitary or borne in umbels available in numerous colors like yellow, orange, pink through scarlet to purple and violet. A wide ranges of variation in colours and ornamental properties which increases the economic importance of cut flower. In many countries the international demand for Alstroemeria flowers has also expanded and it has become one of the most important commercial cut flower for presentation and interior decoration. Alstroemeria can be grown throughout the year but the best planting time in mid hills is July to September.

It is introduced in India as a new cut flower crop and has gaining popularity in markets having a long stem flowers, prolonged vase life and various color and shades of petals. 
Alstroemeria is grown commercially under protected condition for cut flower production. It is being grown in Sikkim and other states under wide range of climatic conditions. Alstroemeria like all other flowering plants are directly or indirectly influenced by the environmental factors like temperature, humidity, wind, soil type etc. and all the varieties responses differently. As the commercial cultivation of cut flowers have a good potential; introduction and popularization of high yielding cultivars of Alstroemeria gaining importance. Evaluation of Alstroemeria for vegetative and flowering characteristic under polyhouse for commercial cultivation as cut flowers has a good potential. In Sikkim it is growing as a cut flower under poly house as well as in open field condition. It reflects its good growing potential in the area. So far, no scientific studies have been done on varietal screening of Alstroemeria under Sikkim agro-climatic conditions.

\section{Materials and Methods}

The experiment was carried out on eight cultivars of Alstroemeria viz, Rosita (V1), Picanto (V2), New Pink (V3), Tiara (V4), Reena (V5), Aladdin (V6), Flaming Star (V7), Lemon (V8) at Sribadam west Sikkim during August 2015 to April 2016 to evaluate the performance under poly house conditions. Experimental material consist of 8 cultivars of Alstroemeria were collected from farmer's field. The site is located in West District of Sikkim at N- $27^{\circ} 13.065^{\prime}$ and E- $88^{\circ} 12.524$ and $5749 \mathrm{ft}$. above mean sea level. This place is considered to be mild temperate rainy region. The soils of experimental field were red and sandy loam with adequate drainage and optimum water holding capacity and having the $\mathrm{pH}$ 6.4. The experiment was laid out in complete randomized block design with four replications. Eight plants from each cultivar in each replication were used for record the observations. The net plot size was
$1 \mathrm{~m} \times 6 \mathrm{~m}$ and raise to a height of $30 \mathrm{~cm}$ from the soil surface. Well decomposed FYM @ $5 \mathrm{~kg} / \mathrm{m}^{2}$ were applied as basal dose to each plot 10 days before planting. Uniform and healthy plants were planted in the month of August, 2015 under polyhouse conditions at spacing of $50 \mathrm{~cm} \times 50 \mathrm{~cm}$ between rows and plants and maintained uniform cultural practices. The experiment was laid under naturally ventilated medium cost polyhouse condition fabricated with UV stabilized polyfilm (200 micron) as a cladding material. The data were recorded from each cultivars in each replication for growth and flowering characters. Observations were recorded and analysed using the analysis of variance (ANOVA) technique and treatments were compared at 5\% level of significance.

\section{Results and Discussion}

Mean pooled data in respect of various vegetative and flowering parameters were studied on eight different cultivars under polyhouse conditions. The data were presented in Table 1 and Table 2 for vegetative and flowering parameters respectively.

Data presented in Table 1 indicated that cultivars showed significant variation for days taken for rhizome to sprout, height gained at every 15 days interval number of leaves per spike at flower bud emergence, number of leaves per spike at flower harvesting stage and leaf area. Among the cultivars studied, cultivar V3 took minimum days to sprout (11.85) followed by V6 (12.28) and maximum was recorded in cultivar V5 (27.85). Plant height gained recorded maximum in cultivar V3 $(33.53 \mathrm{~cm})$ followed by V6 $(21.33 \mathrm{~cm})$ and minimum was recorded in cultivar V8 (11.58 $\mathrm{cm})$ at day $70^{\text {th }}$. Variation may be due to the temperature differences which highly influence the normal growth pattern of the plant reported by Labeke and Dambre (1993) in Alstroemeria. The number of leaves at 
different stages was recorded. The maximum number of leaves per plant at flower bud emerging stage and the maximum number of leaves at flower harvesting was recorded under variety V1 (26.5 and 38.48, respectively) whereas the minimum number of leaves per plant was recorded under variety V2 (20.5). On the other hand the minimum number of leaves at flower harvesting was observed under variety V5 (27.13). Cultivar V1 was recorded maximum leaf area (41.68 $\mathrm{cm})$ followed by V3 $\left(39.98 \mathrm{~cm}^{2}\right)$ whereas minimum was recorded in cultivar V8 (32 $\mathrm{cm}^{2}$ ).

The data for days taken to bud emergence shows highly significant between the varieties. The variety V3 (78.10 days) took maximum days to bud emergence on the other hand variety V1 (61.10 days) shows the minimum days to bud emergence followed by V2 (61.55). Similarly days taken from bud to flowering was recorded maximum in cultivar V1 (24.60 days) whereas the variety V2 shows minimum days from bud to flower (12.60 days) followed by V6 (15.10). The number of cymes per spike shows highly significant between different varieties. Maximum was recorded in cultivar V1 (6.28) followed by V3 (5.93) and minimum was recorded in cultivar
V5 (4.05). The number of florets per spike which is important characteristic of Alstroemeria cut flower shows highly significant different among different varieties which was maximum in cultivar V1 (13.79) followed by V6 (11.78) whereas the minimum was recorded in varieties V5 (7.73). The maximum spike diameter was recorded in cultivar V1 $(8.83 \mathrm{~mm})$ followed by V2 (6.98 $\mathrm{mm}$ ) while minimum was recorded in cultivar V8 $(5.73 \mathrm{~mm})$. This difference is due to the genetic constitution of the germplasm (Sing, 2006, Panse, 1957)The data for maximum spike length was recorded in cultivar V3 $(138.50 \mathrm{~cm})$ followed by V2 $(108 \mathrm{~cm})$ whereas, the minimum was recorded in cultivar V8 $(80.50 \mathrm{~cm})$. Similarly the maximum peduncle length was recorded in cultivar V3 $(7.13 \mathrm{~cm})$ followed by V1 $(6.50$ $\mathrm{cm})$ hence the minimum was recorded in cultivar V8 $(3.48 \mathrm{~cm})$. The days taken for first bud to open was maximum in cultivar V5 (5.43 days) whereas, V8 (3.68 days) took minimum days for first bud to open followed by V2 (3.73). The days taken to maximum bud opening between different varieties was found maximum in cultivar V5 (7.48 days). However, variety V2 (5.45 days) took minimum days for maximum bud opening followed by V7 (5.48 days).

Table.1 Vegetative growth parameters of Alstroemeria cultivars grown under Sikkim condition

\begin{tabular}{|c|c|c|c|c|c|c|c|c|c|}
\hline \multirow{2}{*}{$\begin{array}{l}\text { Observation } \\
\text { varieties }\end{array}$} & \multirow{2}{*}{$\begin{array}{l}\text { Days } \\
\text { taken for } \\
\text { rhizome } \\
\text { to sprout }\end{array}$} & \multicolumn{5}{|c|}{ Height gained at every 15 days interval $(\mathrm{cm})$} & \multirow[b]{2}{*}{$\begin{array}{l}\text { Number } \\
\text { of leaves } \\
\text { per spike } \\
\text { at flower } \\
\text { bud } \\
\text { emergence }\end{array}$} & \multirow[b]{2}{*}{$\begin{array}{c}\text { Number } \\
\text { of leaves } \\
\text { per spike } \\
\text { at flower } \\
\text { harvesting } \\
\text { stage }\end{array}$} & \multirow{2}{*}{$\begin{array}{l}\text { Leaf area } \\
\left(\mathrm{cm}^{2}\right)\end{array}$} \\
\hline & & $\begin{array}{l}\text { DAY } \\
15^{\text {th }}\end{array}$ & $\begin{array}{l}\text { DAY } \\
30^{\text {th }}\end{array}$ & $\begin{array}{l}\text { DAY } \\
45^{\text {th }}\end{array}$ & $\begin{array}{l}\text { DAY } \\
60^{\text {th }}\end{array}$ & $\begin{array}{l}\text { DAY } \\
70^{\text {th }}\end{array}$ & & & \\
\hline Rosita (V1) & 23.43 & 7.15 & 8.43 & 13.1 & 13.3 & 18.1 & 26.5 & 38.48 & 41.68 \\
\hline Picanto (V2) & 16.75 & 9.38 & 11.15 & 13.83 & 16.95 & 18.7 & 20.5 & 28.5 & 33.3 \\
\hline New Pink (V3) & 11.85 & 9.4 & 26.85 & 24.23 & 20.6 & 33.53 & 24.23 & 36.7 & 39.98 \\
\hline Tiara $(\mathrm{V4})$ & 12.48 & 5.7 & 16.8 & 12.88 & 9.1 & 12.98 & 22.73 & 34.4 & 37.88 \\
\hline Reena (V5) & 27.85 & 5.28 & 13.23 & 13.2 & 8.6 & 17.48 & 20.5 & 27.13 & 36.00 \\
\hline Aladdin (V6) & 12.28 & 6.98 & 19.25 & 16.75 & 14.6 & 21.33 & 23.6 & 31.83 & 35.85 \\
\hline $\begin{array}{l}\text { Flaming Star } \\
\text { (V7) }\end{array}$ & 13.00 & 4.93 & 10.4 & 7.58 & 13.88 & 15.05 & 25.23 & 35.78 & 33.6 \\
\hline Lemon (V8) & 25.75 & 4.5 & 8.67 & 10.15 & 8.98 & 11.58 & 21.00 & 29.00 & 32.00 \\
\hline
\end{tabular}


Table.2 Vegetative flowering parameters of Alstroemeria cultivars grown under Sikkim condition

\begin{tabular}{|c|c|c|c|c|c|c|c|c|c|c|c|c|c|c|}
\hline $\begin{array}{l}\text { Observation } \\
\text { varieties }\end{array}$ & $\begin{array}{l}\text { Days } \\
\text { taken to } \\
\text { flower } \\
\text { bud } \\
\text { emergence }\end{array}$ & $\begin{array}{l}\text { Days } \\
\text { taken to } \\
\text { flower } \\
\text { bud } \\
\text { emergence } \\
\text { to } \\
\text { flowering }\end{array}$ & $\begin{array}{l}\text { Number } \\
\text { of } \\
\text { cymes } \\
\text { per } \\
\text { spike }\end{array}$ & $\begin{array}{l}\text { Number } \\
\text { of } \\
\text { florets } \\
\text { per } \\
\text { spike }\end{array}$ & $\begin{array}{l}\text { Spike } \\
\text { diameter } \\
(\mathbf{m m})\end{array}$ & $\begin{array}{l}\text { Spike } \\
\text { length } \\
\text { (cm) }\end{array}$ & $\begin{array}{l}\text { Peduncle } \\
\text { length } \\
\text { (cm) }\end{array}$ & $\begin{array}{l}\text { Days } \\
\text { for } \\
\text { one } \\
\text { floret } \\
\text { to } \\
\text { open }\end{array}$ & $\begin{array}{l}\text { Days for } \\
\text { maximum } \\
\text { florets to } \\
\text { open }\end{array}$ & $\begin{array}{l}\text { Total } \\
\text { florets } \\
\text { opened } \\
\text { per } \\
\text { spike } \\
(\%)\end{array}$ & $\begin{array}{l}\text { Spike } \\
\text { fresh } \\
\text { weight } \\
\text { (g) }\end{array}$ & $\begin{array}{l}\text { Spike } \\
\text { fresh } \\
\text { weight } \\
\text { loss } \\
\text { (g) }\end{array}$ & $\begin{array}{l}\text { Water } \\
\text { uptake } \\
(\mathbf{m l})\end{array}$ & $\begin{array}{l}\text { Vase } \\
\text { life } \\
\text { (Days) }\end{array}$ \\
\hline Rosita (V1) & 61.10 & 24.60 & 6.28 & 13.79 & 8.83 & 82.88 & 6.50 & 4.28 & 6.05 & 86.13 & 54.92 & 4.78 & 46.15 & 12.58 \\
\hline $\begin{array}{l}\text { Picanto } \\
\text { (V2) }\end{array}$ & 61.55 & 12.60 & 4.78 & 9.3 & 6.98 & 108.00 & 4.63 & 3.73 & 5.45 & 90.58 & 42.35 & 8.1 & 37.93 & 13.58 \\
\hline $\begin{array}{ll}\text { New } & \text { Pink } \\
\text { (V3) } & \end{array}$ & 78.10 & 20.35 & 5.93 & 10.73 & 6.9 & 138.50 & 7.13 & 3.83 & 5.93 & 82.15 & 36.03 & 4.68 & 38.3 & 11.78 \\
\hline Tiara (V4) & 75.80 & 26.48 & 5.80 & 11.55 & 6.1 & 91.27 & 5.23 & 5.05 & 6.65 & 68.68 & 29.17 & 3.15 & 40.05 & 11.28 \\
\hline Reena (V5) & 69.08 & 18.40 & 4.05 & 7.73 & 5.88 & 82.40 & 4.30 & 5.43 & 7.48 & 66.25 & 30.73 & 4.4 & 26.3 & 11.68 \\
\hline $\begin{array}{l}\text { Aladdin } \\
\text { (V6) }\end{array}$ & 76.35 & 15.10 & 5.53 & 11.78 & 6.23 & 117.55 & 4.98 & 4.3 & 6.05 & 73.5 & 30.86 & 5.58 & 39.93 & 13.33 \\
\hline $\begin{array}{l}\text { Flaming } \\
\text { Star (V7) }\end{array}$ & 62.95 & 17.23 & 5.03 & 10.4 & 6.68 & 105.73 & 4.60 & 4.23 & 5.48 & 74.18 & 35.98 & 3.38 & 30.35 & 12.9 \\
\hline Lemon (V8) & 77.75 & 18.00 & 4.38 & 9.5 & 5.73 & 80.50 & 3.48 & 3.68 & 5.93 & 63.8 & 20.78 & 7.7 & 24.00 & 10.18 \\
\hline
\end{tabular}


The number of opened florets per spike was highly significant between different varieties. The maximum number of opened florets was found to in the variety V2 $(90.58 \%)$ followed by V1 $(86.13 \%)$ whereas, minimum number of florets opened per spike was recorded in variety V8 $(63.8 \%)$.

Data for average fresh weight of different varieties shows highly significant. The maximum fresh weight was recorded in the variety V1 (54.92) followed by V2 (42.35) however, the minimum average fresh weight was recorded in variety V8 (20.78).

The average fresh weight loss of different varieties, where the maximum weight loss was recorded in the variety $\mathrm{V} 2(8.1 \mathrm{~g})$ and the minimum was recorded in the variety V4 (3.15 g) followed by V7 (3.38).

Significantly maximum water uptake by the spike under vase life study was recorded under variety V1 (46.15 ml) followed by V4 (40.05) however, the minimum water uptake was recorded in variety $\mathrm{V} 8(24 \mathrm{ml})$.

Shelf life of cut Flower is an important trait which decides its longevity in vase as well as in decorations.

The average vase life of different Alstroemeria varieties was highly significant between the different cultivars and was recorded in cultivar V2 (13.58 days) followed by V7 (12.9 days) and it was recorded minimum in cultivar V8 (10.18 days).

The study was conducted with 8 cultivars of Alstroemeria under polyhouse to evaluate their performance for growth and flowering. Based on overall performance of eight Alstroemeria varieties, V1 (Rosita), V2 (Picanto), V3 (New Pink) and V4 (Tiara) were found to be promising. These varieties performed better than other varieties under Sikkim agro-climatic condition. Therefore, these varieties can be utilized as standard cut flower production in Sikkim. Selecting variety for early production V3 (New Pink), V4 (Tiara) and V6 (Aladdin) can be the best and for late production V5 (Reena) and V1 (Rosita) can be used.

\section{References}

Bridgen, M.P. (1993). Alstroemeria. In: The Physiology of Flower Bulbs (Eds., De Hertogh and Marcel Lenard). Elsevier Science Publishing, The Netherlands, pp. 201-9.

De Hertogh (1989). Alstroemeria cut flower. Holland Bulbs Forcer's Guide. Section C-1.

Labeke, M.C. Van and Dambre, P. (1993). Response of five Alstroemeria cultivars to soil cooling and supplementary lighting. Scientia Horticulturae, 2(56): 135-145.

Lisiecka, A. and Szczepaniak, S. (1992). Factors influencing the yield of Alstroemeria. Acta Horticulture, 3 (25): 379-386.

Łukaszewska, A., Tatol, A. and Guenther, A. (2008). Evaluation of postharvest quality of the Polish cultivars of Alstroemeria hybrida. Horticulture and Landscape Architecture, 29: 31-38.

Panse, V.G. (1957). Genetics of quantitative characters in relation to plant breeding. Indian Journal of Genetic and Plant Breeding, 17: 318-328.

Robinson, G.W. (1983). Alstroemeria. Journal of Royal Horticultural Society, pp. 490-494.

Singh, M.K. (2006). Performance of Alstroemeria cultivars under polyhouse conditions. Indian Journal of Horticulture, 63 (2): 195198.

\section{How to cite this article:}

Sujit Rai and Manju Rana. 2019. Comparative Evaluation of Growth and Flowering Characteristic of Alstroemeria Varieties under Sikkim Condition. Int.J.Curr.Microbiol.App.Sci. 8(08): 929-933. doi: https://doi.org/10.20546/ijcmas.2019.808.107 